\title{
TAXING DIGITAL ADVERTISING: A PROPOSAL TO INDONESIA Galih Ardin
}

The National Graduate Institute for Policy Studies, Tokyo. Email: MEF19502@grips.ac.jp

\section{ABSTRACT}

Tax on digital economy activities has become a widely discussed issue in the world because of the limitation on the permanent establishment concept in anticipating the digital economy's externalities. The failure of OECD countries to reach digital economic taxation agreements also caused these countries to take unilateral measures in securing their respective interests. Indonesia, as a country with considerable digital economy value in the Southeast Asia region, plans to implement the significant economic presence concept to secure its tax revenue that cannot be captured by PE concept in the digital cross-border transaction. However, the implementation of this new nexus could generate new challenges in the Indonesia taxation system. This study seeks to provide alternatives to the Indonesian government regarding the taxable presence and taxation methods on the digital economy, especially digital advertising, by conducting examination and evaluation through current nexuses, the international proposals, and other countries' experience in addressing tax challenges in the digital advertising.

Keywords: international taxation, digital taxation, digital economy, permanent establishment, digital advertising, nexus

\section{ABSTRAK}

Pajak atas aktifitas ekonomi telah menjadi sebuah isu yang berkembang luas di kalangan masyarakat dunia. Hal ini dikarenakan keterbatasan konsep BUT dalam mengantisipasi transaksi digital tersebut. Kegagalan negara-negara OECD dalam mencapai kesepakatan atas pemajakan ekonomi digital juga menyebabkan masing-masing negara mengambil langkah antisipatif pemajakan sendiri sesuai dengan kepentingan nasionalnya. Indonesia, sebuah negara dengan nilai ekonomi digital terbesar di kawasan Asia Tenggara, berencana untuk 
menerapkan konsep kehadiran ekonomi signifikan (significant economic presence) untuk mengamankan pendapatan pajaknya yang tidak dapat ditangkap oleh konsep BUT dalam transaksi internasional. Namun demikian, implementasi konsep baru ini dapat menimbulkan tantangan baru di dalam sistem perpajakan Indonesia. Kajian ini berusaha memberikan alternatif kepada Pemerintah Indonesia terkait dasar pemajakan dan metode pemajakan terhadap ekonomi digital, khususnya digital advertising, dengan cara melakukan pengujian dan evaluasi terhadap nexus yang berlaku saat ini, usulan OECD dan pengalaman negara lain dalam menghadapi masalah pajak dalam ekonomi digital.

Kata kunci: perpajakan internasional, perpajakan digital, ekonomi digital, bentuk usaha tetap, periklanan digital, nexus

\section{BACKGROUND}

Google, Temasek, Bain, and Company (2019) reported that the value of the digital economy in Indonesia during 2019 was estimated at USD 40 billion or a fourfold increase compared to 2015. Google et al. (2019) also believe that the average growth of the digital economy in Indonesia is 49\% per year and estimated to reach USD 130 billion in 2025. According to Google et al. (2019), the growth of the digital economic market in Indonesia is the largest and fastest among southeast Asia countries. Furthermore, Das, Gryseels, Sudhir, and Tan (2016) stated that in 2025 the value of the digital economy in Indonesia is estimated to reach USD 150 billion and will create 3.7 million new jobs. One factor that makes the digital economy increase is the massive amount of internet penetration in Indonesia. Kemp (2020) reported that, during January 2020, the number of Indonesian who use the internet was 175.4 billion, or equal to
$64 \%$ of Indonesia's total population, which is an increase of $17 \%$ compared to the previous year.

Unfortunately, according to Susanti, Nasir, and Sukardianti (2017), the increase in the digital economy in Indonesia has not been supported by the updates of tax regulations. As a result, the Indonesian government has difficulty in taxing digitalbased economic activities such as digital advertising. For example, according to Bohang (2018), the Indonesian government is having difficulty collecting taxes on Facebook, even though Facebook has conducted an advertising business in Indonesia for several years. Susanti et al. (2017) argue that the difficulty in taxing the digital economy is partly due to the limitations of the concept of the permanent establishment (hereafter referred to as PE), which is currently still used by the Indonesia taxation system. Darussalam and Ngantung (2018) argue that by the PE nexus, the 
Indonesian government could have imposed taxes on foreign entities if only those entities have physical representatives in Indonesia. However, the digital economy has enabled an entity to conduct its business remotely without any physical representative in source countries like Indonesia.

To avoid the larger potential loss of tax from digital economy activities, in 2020, the Indonesian government plans to expand the PE concept to the Significant Economic Presence (hereafter referred to as SEP) concept in the tax omnibus-law draft. According to the OECD (2014), the significant presence concept allows the tax authority to impose income tax to an entity with an economic interest in a country even though it does not have a branch nor representative office in that source country. The expansion of the PE concept to the SEP concept is challenging and potentially creates other problems regarding the criteria of significance, tax base, and taxation method. According to Darussalam and Ngantung (2018), the expansion of this concept will widen the tax base but do not guarantee tax justice between tax authorities and taxpayers. Therefore, a further study is needed to discuss the implication of the implementationof SEP concept on the current nexus and taxation methods. Unfortunately, up to now, there has been no study in Indonesia that discusses the taxation implication of expanding the concept of PE to a SEP in Indonesia. Therefore, this policy paper will discuss the correlation between SEP nexus and the PE nexus in the Indonesian taxation system. Moreover, this study will also discuss how to impose income tax on the digital transaction under the SEP nexus to create fair taxation right among countries. However, due to the broad scope of the digital economy, this paper will focus only on the tax analysis of the digital advertising business because digital advertising has a significant value in Indonesia and relatively challenging to tax compared to other digital transactions.

This policy paper consists of six chapters. The first chapter is an overview of the tax challenges posed by Indonesia's digital economy and measures taken. The second chapter will discuss the tax challenges in the digital economy, especially about the limitations of the current Indonesian tax provision in dealing with the digital economy. The third chapter will discuss the Indonesian government's efforts to face the tax challenges that arise in the digital economy. Next, the fourth chapter will review the OECD proposal on addressing the tax challenges arising from the digital economy activities. The fifth chapter will discuss and evaluate the proposals that we have made to address the tax challenges posed by the digital economy in the Indonesia taxation system. Finally, the sixth chapter will summarize the discussion in chapters one through five. 


\section{INDONESIAN TAX CHALLENGES ARISING FROM DIGITAL ADVERTISING}

Digital economy development has brought many changes to the way humans behave in economic transactions. According to Susanti et al. (2017), the use of the internet in business has changed from an information exchange tool to an application for business strategies. At this time, the public can easily buy, sell, rent, and conduct other economic transactions with all parties throughout the world without any national border restriction. However, besides providing convenience, the digital economy also creates its challenges. According to OECD (2014), one of the challenges arising from the digital economy is the PE concept limitation in following technological developments in business processes. Hongler and Pistone (2015) argue that the UN and OECD provision regarding PE is no longer suitable for the digital economy's characteristics. In the digital economy, entrepreneurs can conduct their business anywhere without establishing any physical representatives in the country where they are doing business.

On the other hand, under the PE concept, the tax authority could have imposed taxes on non-resident entities only if the non-resident entities have a representative or physical presence in the source country. As a result, the tax authority finds it difficult to impose taxes on the digital economy activities. Therefore, in this section, we will discuss the characteristics of digital economy UN and OECD provisions regarding the permanent establishment, the application of UN and OECD provisions in Indonesia, real examples of PE limitation in Indonesia, and the consequences arising from the limitations of this PE concept.

\subsection{Characteristics of Digital Economy}

According to OECD (2018), the digital transaction has three main characteristics that differ from the traditional one: crossjurisdictional operation, reliance on intangible property, and user participation. Cross-jurisdictional operations mean that digital business can be effectively involved in a country's economy without establishing a physical presence in those countries. As a result, the digital business can obtain economies of scale without any representation or physical presence (OECD, 2018). However, the cross-jurisdictional operation by remote technologies cannot happen without the development of intellectual property rights like patents, goodwill, and trademarks. Therefore, the OECD (2018) argues that intangible property is the value driver in the digital economy, and the reliance on intangible assets is the other critical characteristic in digital economy development. World Intellectual Property Organization (WIPO) argues that during the last decade, intellectual property rights such as industrial designs, patents, trademarks, and copyrights have increased due to the increase in the digital economy (OECD, 2018). 
Furthermore, user participation is essential in digital activities because, without user participation, intellectual properties cannot generate added value in the economy. Analysis of customer data has enabled digital firms to optimize profits by processing and connecting specific user information. For example, digital advertising companies can maximize the commodity seller profits by targeting digital advertising to specific users (OECD, 2018). Understanding these characteristics is important because it gives us a basic understanding of how the digital economy works and makes a difference to the traditional economy.

\subsection{Provisions Regarding Permanent Establishment in UN, OECD and Indonesia}

Hongler and Pistone (2015) argue that PE concept is one of the essential concepts in taxation because it is used to identify whether a tax authority can impose a tax on the income or not. The provision regarding the $P E$ is regulated in the tax treaty and the domestic tax regulation of each country. In general, there are two tax treaty models in the world: the UN model and the OECD model. According to the UN (2019), the two models have the same structure but different aspects. The UN Model and the OECD Model define PE as a fixed place where a business is run in part or a whole in six primary forms, including a place of management, branch, office, workshop, and location for gas or oil mining (OECD, 2017; UN, 2017).

According to OECD (2017), there are three forms of PE: the basic form of PE, construction $\mathrm{PE}$, and agency $\mathrm{PE}$. On the other hand, the UN (2017), argues that there are five forms of the UN model: the basic form of $P E$, construction $P E$, service, agency $P E$, and insurance PE. Based on these PE forms, we can see that the UN model is broader than the OECD model. Darussalam and Ngantung (2018) argue that the UN model has broader PE forms because the UN model is developed for emerging countries or capital importing countries. By expanding the scope of PE, the UN hopes developing countries will obtain greater taxation rights from foreign investments.

The basic form of PE is a fixed place of business, facilities, or installation as regulated in article 5 paragraph (1) UN model and OECD model, including branch, place of management, workshop, office, and other kinds of a fixed place (OECD, 2017; UN, 2017). Darussalam and Ngantung (2018), argue that the entities should meet five criteria to generate PE in the source country. First, the entities should have a business place, installation, or construction to do business. Second, these business places, installation, or construction plan should occupy a specific geographical location. Third, non-resident entities must have the right to utilize the business, installation, or construction site. Fourth, these business places should be permanent or durable in a specific period. Fifth, nonresident entities have the right to use those 
business places, installations, or construction plans. Furthermore, Darussalam and Ngantung (2017) argue that those requirements are cumulative. It has meant that the PE will exist if the non-resident entities meet all of the requirements.

The second form of PE is construction PE. OECD (2017) defines construction PE as building construction, installations, and projects established for more than 12 months. On the other hand, UN (2017) defines construction PE as building construction, assembly or installation, or project or supervision that has been established for more than six months. Based on the above definition, we may see that the UN model gives broader taxation rights to importing capital countries/source countries because the time test in the UN model is shorter than the time test in the OECD Model. Besides regulating the basic form of PE and PE construction, both the OECD and UN models also regulate the third form of $P E$, a services PE. A service PE exists because non-resident entities provide services, including consultation through their employees or other parties in the source country for more than 183 days in 12 months (OECD, 2017; UN, 2017).

In Indonesian domestic regulations, the provisions regarding PE are regulated in a special law adopted in 2008. In this law, PE is defined as a permanent form used by non-resident individuals and non-resident companies that conduct business and deliver services in Indonesia. Several forms of PE are recognized in Indonesia, such as a place of management, branch, representative office, office, factory, workshop, warehouse, a place for promotion, a place for natural mining resources, oil and gas mining areas, fishing places, plantation, construction, independent agents as well as computers and electronic agents owned or used by electronic transaction providers that conductbusiness through the internet.

Furthermore, Indonesian tax provisions also stipulate that there are three criteria considered to generate PE in Indonesia. First, the non-resident entities should have a place of business in Indonesia. Second, those places of business should be in permanent terms. Third, those places of business should be used to conduct business activities (Minister of Finance Regulation [MOF], 2019). The Indonesian tax provision also stipulates that the business place must be used continuously or within a specified period and occupy a specific geographical location to be categorized as PE (MOF, 2019). If the business place of the non-resident entities does not meet any of these criteria, a PE does not exist. As a result, the Indonesian tax authority cannot impose taxes on those foreign entities. At this stage, we can understand why digital advertisers such as Facebook, Bing, Twitter, and other similar companies do not have PE in Indonesia. Theydo not meet the criteria to be classified as permanent establishments since theycan delivertheir service remotely.

According to Darussalam and Ngantung (2018), the tax authority can conduct a PE test to examine whether PE does exist. The PE test includes a place of 
business test, location test, right use test, permanent test, and business activity test. Place of a business test is a test conducted by the tax authority to examine whether the non-resident entities use business premises, facilities, or installations to conduct business activities in Indonesia. Next, the tax authority can overseea location test to examine whether a place of business, facility, or installation being tested occupies a specific geographic location. For example, operating a bus by a non-resident entity will not generate a PE because it is a movable asset. On the other hand, the operation of a bus ticket sales booth by a non-resident entity will lead to a PE because it involves a fixed place of business (Darussalam and Ngantung, 2018).

On the other hand, tax authorities can conduct the right use test to examine whether the non-resident entities have the right to use the place of business, facility, or installation being tested. If non-residents entities have the right to use the place of business, this condition does not mean that non-resident entities must own this place of business. The tax authority can conduct a permanent test to check whether nonresident entities use the business premises, facilities, or installations continuously or for a specified period. If the facilities and plants tested are not used continuously, PE does not exist. Furthermore, Darussalam and Ngantung (2018) argued that the PE testing criteria mentioned above are collective, meaning that PE does not exist if one of the $P E$ criteria is not met.

As an illustration, we can see Figure 1. In Figure 1, five PE tests must be passed to determine the existence of PE. If the answer to the first question is no, the PE does not exist. Vice versa, if the answer to the first question is "yes", the test continues to the second question. Suppose that we will test the digital advertising activities carried out by Instagram. The first question has the "yes" answer because, in reality, Instagram is doing digital advertising business in Indonesia. Next, the second question has the "no" answer because Instagram has no fixed place in Indonesia. Based on the second test, we can conclude that PE does

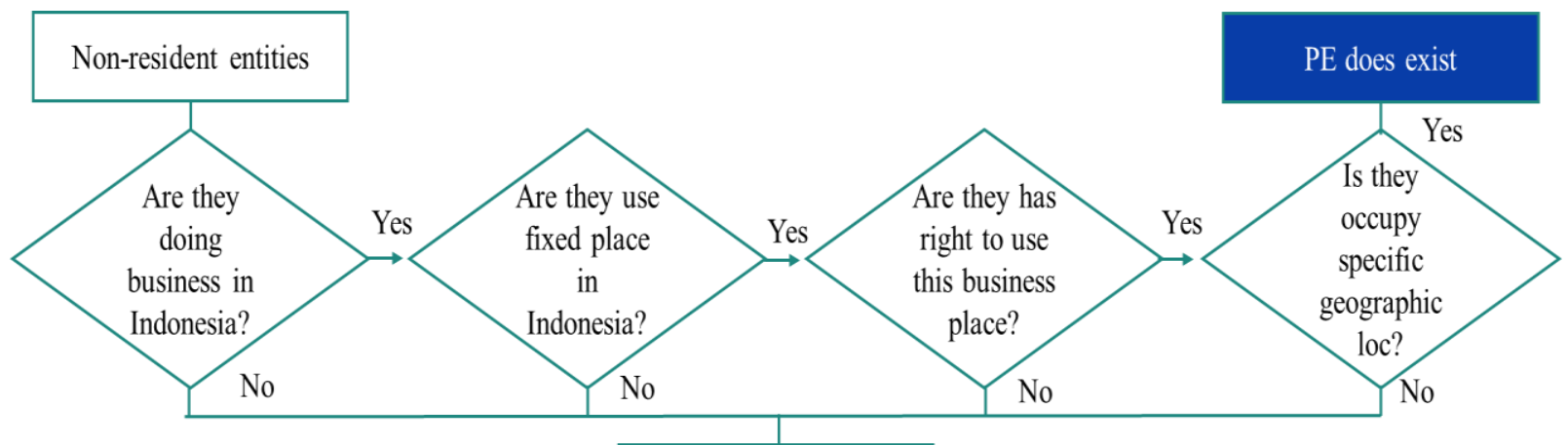

PE does not exist

Figure $1 \mathrm{PE}$ test diagram 
not exist for Instagram activities in Indonesia, even though for these activities, Instagram obtains advertising revenue from Indonesia.

\subsection{Implications of Digital Economy Tax Challenges}

Google and Facebook tax disputes are a few examples of tax challenges that arise due to the limitations of the PE concept in anticipating the development of the digital economy, especially digital advertising. Unless appropriate action is taken immediately, the tax dispute and potential losses that arise will be even more considerable. Statista (2020) reports that digital advertising in Indonesia has a very rapid development. In 2015 alone, the value of digital advertising spending in Indonesia amounted to 918 million USD. This numberwill increase to 1 billion USD by 2020 and is expected to reach 2 billion USD by 2024 (Statista, 2020). Statista noted that from 2017 to 2020, the value of digital advertising spending per capita increased by an average of 2 USD per capita. This fact shows that the digital advertising industry is an industry that attracts investors and will continue to grow in the next future in Indonesia. Google et al. (2020) also stated that, in 2020, the value of digital advertising in Indonesia will be the largest in Southeast Asia and is expected to continue to grow until it reaches 9 billion USD in 2025. Therefore, it will be damaging to the Indonesian government unless it takes significant action to changes its tax provisions immediately.

\section{INDONESIAN EFFORT IN ADDRESSING THOSE TAX CHALLENGES}

To overcome the tax challenge that arises from the digital economy, the Indonesian government has made several efforts. One of them is to issue Minister of Finance Regulation Number 38 of 2019 concerning the Permanent Establishment. Through this regulation, the Indonesian government seeks to expand the PE definition by including computers, electronic agents, and automatic equipment owned or leased by non-resident entities (MOF, 2019). Therefore, based on this regulation, if Facebook, Instagram, WhatsApp, or other digital advertising companies build servers, network cables, routers, or other electronic equipment in Indonesia, these activities will be considered to generate a PE status in Indonesia.

This provision also tries to broaden PE's definition by including services PE and agency PE. According to Indonesian domestic rule, service PE is a PE that exists because the employees of non-resident entities provide services in Indonesia for more than 60 days in one year. On the other hand, agency PE is a PE that exists if a person or entity acts on behalf of nonresident entities to conduct business in Indonesia (MOF, 2019). Although the Indonesian government has tried to broaden the definition of $P E$, in reality, many digital entities are operating in Indonesia without establishing PE and paying taxes in Indonesia. Comprehensive action is needed to overcome the problem of digital taxation. 


\subsection{Significant Economic Presence Nexus}

Realizing the importance of digital taxation, in March 2020, the Indonesian government issued Government Regulation number 1 of 2020 concerning the State's Financial Policy and Financial System Stability for Handling the Coronavirus Pandemic. One of the main points of this government regulation is the taxation aspects of digital economy activities. Through this regulation, the Indonesia government regulates that foreign traders, foreign service providers, trade operators through foreign electronic systems that meet the provisions of economic significance can generate a taxable presence and subject to income tax or electronic transactions tax (Government of Indonesia [GOI], 2020).

Apart from that, this regulation also stipulates three criteria that can generate a taxable presence in the SEP concept. First, the gross turnover of business groups has to exceed a certain threshold. Second, sales in Indonesia have to be above the specified threshold. Third, the number of active digital media users in Indonesia has to exceed a certain amount (GOl, 2020). If a nonresident entity meets the SEP criteria but cannot generate a PE due to a tax treaty, the non-resident entities are subject to an electronic transaction tax. The Indonesian SEP concept's detail can be explained in Figure 2.

Based on Figure 2, we may see that if the non-resident entities meet one of the SEP test criteria, two possibilities will emerge. First, if there is no tax treaty provision that specifically regulates the establishment of $P E$, the PE will exist. Moreover, this activity is subject to income tax under Indonesian domestic tax regulations. Second, if the PE cannot be generated due to a special provision in the tax treaty, PE does not exist, and this activity is subject to the electronic transaction tax. However, if the taxpayer does not meet all the SEP criteria, the PE

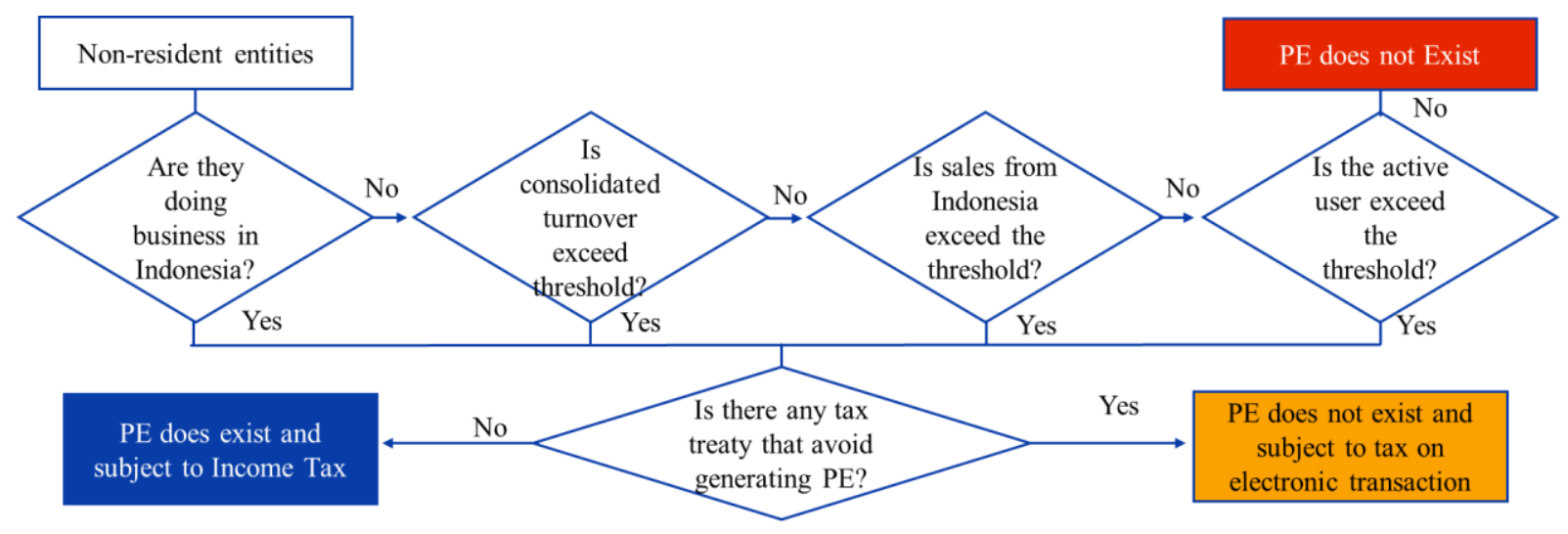

Figure 2 SEP test diagram 
does not exist. As a result, the Indonesian government cannot impose a tax on the non-resident entities.

\subsection{Limitations of SEP Nexus}

At this stage, it can be seen that, according to the Indonesian Government, the SEP concept is a solution to the limitations of the PE concept. The SEP concept broadens the tax base by taxing activities that are generally difficult to tax under the PE concept. However, the SEP concept, as regulated in the above provision, still contains problems. First, the regulation does not explain whether the SEP concept acts as a replacement or a complement to the PE concept. According to Hongler and Pistone (2015), the relationship between the new nexus, the current nexus, and other articles in the taxtreaty must be linked clearly. Second, the concept of SEP creates a new type of tax, namely electronic transaction tax. Unfortunately, up to now, the Indonesian government has not determined the type and mechanism of this electronic transaction tax. In the next section, we will discuss the relationship between the SEP concept and the PE concept under the Indonesian taxation system. We will also discuss the forms and types of electronic transactions tax.

\section{UNDERSTANDING THE OECD PROPOSAL}

The OECD, an international institution that is concerned about international tax issues, basically has offered proposals on the taxable presence and taxation method in order to address tax issues on digital transactions. However, to date, OECD countries have not reached an agreement on which proposals will be used in international taxation practices (OECD, 2020). The knowledge about the OECD proposals and implementation in several countries is essential in designing the relationship between SEP and PE and taxation methods suitable for the digital economy.

\subsection{OECD Proposal Regarding Taxable Presence}

Through BEPS action plan number 7, OECD (2014) tries to overcome the limitations of the PE nexus by proposing several changes: modifying the PE exception, creating a new nexus based on a significant digital presence, and replacing PE with a significant presence of nexus. The knowledge about this BEPS action plan will give us a broader sight about OECD alternatives and implications in addressing PE limitation in the digital economy.

According to the OECD (2014), the first option proposed regarding PE nexus is modifying supporting and auxiliary activities as regulated in the article 5 paragraph (4) OECD Model Tax Convention on Income and on Capital (hereafter referred to as OECD MTC). Based on OECD MTC, the preparation or auxiliary facilities such as storage, display, delivery, and information gathering generally do not give rise to PE 
even though these supporting facilities provide the significant added value in the digital economy activities (OECD, 2017). For example, even though Facebook earns income from supporting activities such as gathering information about consumer preference and behavior in Indonesia, those activities do not merely generate PE status of Facebook in Indonesia. Therefore, the Indonesian tax authority cannot impose a tax on Facebook supporting activities. From this point of view, the OECD proposes to modify or eliminate the article 5 paragraph (4) OECD MTC in part or a whole (OECD, 2014). OECD (2014) argues that the modification or elimination of article 5 (4) aims to give better taxation right to the source country by enabling source country to tax the preparation and auxiliary activities in the digital economy.

The second alternative proposed by the OECD to overcome the digital challenge in PE nexus is to apply a significant digital presence concept for digital business activities. Under this proposal, OECD (2014) argues that business activities can create a PE in the source country if they meet the significance of digital presence. The significant digital presence assumes that the taxable presence in the source country exists if it satisfies specific conditions such as whether the foreign company has several significant contracts with consumers domiciled in the source country, whether digital goods or services provided by foreign companies are widely used in source countries, whether there are some significant payments from consumers domiciled in the source country to foreign companies and whether there are branches of foreign companies in source countries that carry out marketing and consulting functions.

The third alternative offered by OECD is to replace the PE concept with a significant presence concept. Under the significance presence concept, OECD (2014) argues that a taxable presence exists in the source country if the sale of goods or services by the foreign company involves a close relationship with a client in the source country. The tax authority may conduct series of test to prove the term "close relationship" by formulating some questions such as whether the foreign company provides websites in local languages, whether the foreign company provides delivery service in the source country, whether the foreign company uses any banking services in the source country and whether the foreign company offers goods or services originating from the source country. Moreover, this proposal also regulates that taxable presence is considered to exist in the source country if foreign companies provide goods or services to domestic consumers that involve systematic data gathering or contribution from parties in the source country. However, each of these proposals has its advantages and disadvantages to prevent profit shifting and base erosion in the digital economy. In the analysis section, we will have more indepth discussion regarding the advantages and disadvantages of each proposal compared to Indonesia's current nexus. 


\subsection{OECD Proposal in Taxing Method}

In 2018, OECD (2018) proposed several methods, including withholding tax, turnover tax, and special measures to big MNE to overcome the challenge in imposing taxes on digital advertising. According to the OECD (2020), up to present, OECD countries have not reached an agreement on which policy options to implement because of differences in interests between developed and developing countries. By understanding those policy options, we can evaluate the strengths and weaknesses of those policies to formulate the new policy.

The first policy option proposed by the OECD is withholding tax. According to the OECD (2018), generally withholding tax is imposed on passive income received by non-resident entities that do not have a PE in the source country. Non-resident entities' activities do not cause PE in source countries because they are generally excluded from PE as regulated in articles 10, 11, and 12 of the OECD MTC. Based on these provisions, income in the form of royalties, dividends, and interest does not cause PE existence but is subject to withholding tax in the source country. However, along with technological developments, there is no clear limit with regards to active income or passive income. As a result, tax authority finds difficulty in making decision whether an activity is subject to withholding tax or not. For example, some tax authorities have difficulty determining whether the income received by cloud computing companies is categorized as income from service, rent, or technical service.

The second policy option proposed by the OECD is the turnover tax. According to OECD (2018), technological developments have prompted several countries to take several actions outside the income tax framework. The main objective of their action is to secure their respective taxation interests. These actions generally target income from sectoral activities such as digital advertising. Countries that have implemented turnover tax are India, Hungary, Italy, and France. Turnover tax is generally combined with a nexus that focuses on where supplies are. Besides, turnover taxes are generally subject to both resident and non-resident taxpayers regardless of where they are. For example, France imposes a tax on audiovisual based on the location of its audience. Likewise, Hungaria also imposes taxes on digital advertising based on the location of the viewer or audience.

The third policy proposed by the OECD to overcome tax challenges in the digital economy is the special regime targeting MNE. According to OECD (2018), this policy is not specifically targeting digital business activities. However, in some cases, this policy is appropriate for highly digitalized activities because the rapid development of the digital economy has given rise to many kinds of business models and tax planning conducted by big MNE. Some countries that have implemented special regimes targeting big MNEs are the UK, Australia, Italy, and the US. In this case, the UK and Australia apply 
Diverted Profit Tax (hereafter referred to as DPT) to tax big MNE. On the other hand, Italy uses enhanced procedures, and the US uses the Base Erosion and Anti-abuse Tax (hereafter referred to as BEAT) to avoid profit shifting from large companies in the US.

According to OECD (2018), the DPT works by imposing a higher tax rate on big MNEs that divert their profits outside the UK. According to OECD (2018), the UK government imposes 19\% corporate income tax on companies registered in the UK. However, if the company diverts its profits outside the UK, the UK government will impose DPT as much as 25\% of net income. OECD (2018) believes that the DPT is a separate tax that differs from other types of taxes in the UK. Furthermore, OECD (2018) argues that one of the DPT's main goals is to increase access to information of the UK tax authority on the MNE's activities and value chain. Therefore, according to OECD (2018), the UK tax authority will conduct observations and dialogue with MNE for 12 months before imposing the DPT. OECD (2018) also argues that the implementation of the DPT has shown excellent results in several countries in terms of tax revenue and transparency behavior. However, according to OECD (2018), DPT adoption is technically complicated and more complex rather than the other taxation methods. Therefore, the implementation of the DPT requires high investment in terms of training and certification of tax officers. In the next subchapter, we will further discuss the DPT implementation in the UK.
Similar to the UK, the US government adopted BEAT with the primary objective to avoid the profit-shifting of big MNE from the US to overseas (OECD, 2018). Moreover, OECD (2018) also argues that the BEAT does not explicitly target the digital business. The BEAT works by providing a minimum income tax rate to big MNEs who invest their profits in the US. As a result, US companies reduce the number of dividends, interest, rent, and similar outbound payments from the US to abroad.

\subsection{Proposal in Addressing Tax Challenge in Digitalization of Economy}

In order to address the challenge in digitalization of economy, OECD (2021) established a new framework for international tax reform stated in pillar one and pillar two. Until July 2021, as many as 130 countries have agreed to implement pillar one and two, which are expected to be effective in 2023. According to the OECD (2021), these 130 countries represent $90 \%$ of GDP worldwide.

Under pillar one, the OECD (2021) states that a new nexus will be formed in market jurisdictions if an MNE earns a minimum income of 1 million euros or equal to 16,8 billion rupiahs. For a judiciary market with a GDP of fewer than 40 billion euros, the threshold will be set at 250.000 euros or equal to 4,2 billion rupiahs. According to the OECD (2021), this pillar one is only binding on MNEs with a global turnover of 20 billion euros and profit before tax below 10\%. The 
main objective of pillar one is to make sure that there is a fair distribution of income and taxation rights between countries (OECD, 2021). Before the application of Pillar One in 2022, all forms of digital service tax will be abolished beforehand. The goal is to reduce the distortion that may be caused by the application of pillar one and DST.

On the other hand, under pillar two, OECD (2021) stated that the source jurisdiction might impose a minimum tax of at least $15 \%$. The purpose of pillar two is to reduce tax competition in corporate income tax by introducing a global minimum corporate tax. According to the OECD (2021), source jurisdictions can protect their tax base by implementing pillar two. Furthermore, OECD (2021) argues that pillar two only determines the limits in corporate income tax but does not eliminate tax competition per se.

\subsection{Other Country Approach}

Our knowledge of OECD proposals will be complete if we grasp the understanding of the application of OECD ideas and concepts by several countries. The three countries that we will be reviewed are India, UK, and Japan. The author chose India as the first example because India has similarities with Indonesia in terms of economic growth, demographic, and socio-cultural conditions. Furthermore, the authors chose the UK as a second example because the UK has experience in handling tax disputes arising from the digital advertising business. Finally, the authors chose Japan as the third example because Japan has a robust economic relationship with Indonesia.

The first example is India. According to the OECD (2018), in 2016, India introduced India Equations levy (EL) as part of the implementation of the BEPS action plan 2015. EL is a new type of tax imposed on digital advertising activities carried out by non-resident entities. The effective rate of $\mathrm{EL}$ is $6 \%$ of all entity's turnover, not income tax. However, EL has four characteristics that make it different from other types of taxes. First, EL is charged for payments from India to parties outside India. This condition indicates that EL only applies to business to business (B2B) transactions. Second, EL is only imposed on activities that have been determined by the government, such as digital advertising or providing space for digital advertising. Third, EL is only subject to payments of more than INR 100,000 (or the equivalent of USD 1,500). Fourth, EL is not imposed if non-resident entities have PE in India. According to OECD (2018), the Indian government does not categorize EL as part of income tax. However, the Indian government classifies EL as part of the transaction-based tax imposed on the number of payments received by nonresident entities. This condition causes as if EL does not cause double taxation under Indian domestic tax law or an Indian tax treaty. EL gives rise to double taxation for non-resident entities.

The second example is the UK. According to Fuchs (2018), in 2015, the UK government issued regulations regarding Diverted Profit Tax as part of the 2015 
finance bill to overcome the profit shifting on the digital economy transaction. In this provision, the UK government imposes a higher tax rate to a company that shifts its profit to other countries. The effective tax rate of DPT is $25 \%$, whereas the ordinary corporate income tax is $18 \%$. This provision is expected to prevent the transfer of profits from the UK to other countries. Fuchs (2018) argues that DPT is often referred to as Google tax because Google is a prime example of transnational companies involved in tax avoidance practices. According to OECD (2018), the main target of the DPT is to reduce artificial tax avoidance by non-resident companies. Generally, non-resident companies orchestrate artificial tax avoidance in the UK by avoiding generating PE.

OECD (2018) argues that DPT consist of two main aspects: a rule on avoided PE and a rule on the alternative provision. A rule on avoided PE focuses on companies conducting activities in the UK but deliberately avoids PE in the UK. One of the targets of this provision is to impose a tax on overseas companies that enter into contracts with final customers in the UK with the help of local staff or company. Generally, these overseas companies do not use branches or representatives to avoid PE existence in the UK. This rule allows the UK tax authority to impose a tax on those overseas companies after conducting a review period of 12 months. Moreover, the OECD (2018) argues that the UK tax authority is using the best estimation that rationally made under income tax and transfers pricing regulations to calculates the tax amount of those overseas companies.

On the other hand, the rule on alternative provision focuses on intra-group transactions involving UK residents with non-UK residents despite having PE or not. According to OECD (2018), the rule on alternative provision, generally targeting transactions that involve licenses, intellectual property transfers, and management consultations carried out by companies in one group. Moreover, OECD (2018) also argues the UK tax authority can apply this regulation not only on diverted profit but also under-reported profit of MNE in the UK. In addition, this regulation applies to all economic sectors and not limited to the digital economy. However, OECD (2018) argues that the UK tax authority generally combines DPT with a high sales threshold because the DPT focuses on MNEs with high turnovers such as Google and Facebook. The OECD (2018) argues that the DPT has a different tax rate than CIT because it is intended to provide a deterrent effect to MNE that intends to shift its profits outside the UK. Yet, Fuchs (2018) believes that the DPT is less effective in reducing the profit shifting in the UK. This condition occurs since big MNE can still divert its profits to its overseas subsidiaries even though the UK government has imposed a DPT. Moreover, the OECD (2018) argues that the implementation of DPT is technically challenging and requires significant investment in thuman resource development of tax authority. 
The third example is Japan. According to Darcy (2019), there are three types of permanent establishments in Japan: branch $P E$, construction PE, and agency PE. The tax authority in Japan taxes foreign companies depending on the type of PE that exists in Japan. Foreign companies that do not have PE in Japan must report through tax returns that the income earned in Japan is not attributed to PE. Furthermore, Darcy (2019) also states that if a foreign entity does not have a PE in Japan, it will only be taxed in Japan on a certain income, such as income derived from the operation or ownership of property assets in Japan, income derived from Personal service provided in Japan, income derived from leasing property in Japan. Besides, income from sales of assets, property, mining rights, shares, or other investments, as well as substantial shares such as warrants and options, will also be taxed in Japan. Japanese domestic regulations stipulate that other income such as income from damage insurance whose assets are in Japan, income from donations received from assets in Japan, income from inventories, receipt of prizes for competitions conducted in Japan and profits Other economies of business or assets located in Japan are taxed even though the business or assets are used or owned by a foreign company without going through a permanent establishment. It shows that until 2019, tax authorities in Japan still adhere to the concept of PE as a taxable presence. Besides, the Japanese tax authority also does not explicitly regulate the digital economy tax.

\section{DESIGNING TAX POLICY FOR DIGITAL ADVERTISING}

As an essential part of this policy paper, this chapter will evaluate Indonesia's current policy regarding the PE and taxation methods to provide policy options as measures to address tax challenges in the digital economy. However, we will use the knowledge and discussion from chapter one to chapter four as the basis for the policy formulation and evaluation in this chapter. We will start our discussion in this chapter by evaluating the taxable presence provision in Indonesia to redesign the relationship between PE concepts and SEP concepts in the Indonesian taxation system. After redesigning the PE and SEP concept, we will continue our discussion with formulating tax methods in digital advertising by evaluating the OECD proposals and other countries' measures. Lastly, we will evaluate the application of proposed policies in the Indonesian taxation system at the end of this chapter.

\subsection{Redesigning the Relation of PE and SEP Concept}

From the previous explanation, we may know that two taxation nexuses currently work in Indonesia: PE and SEP concept, but unfortunately, up to now, the Indonesian government has not set further regulations regarding the SEP concept. The Indonesian government has not regulated whether the SEP concept will replace the PE concept or whether it works as a compliment. The 
Indonesian government also has not provided additional provisions regarding the compatibility of the SEP concept to international best practices.

In general, each nexus has its advantages and disadvantages. For several decades, the PE concept has effectively reduced the practice of base erosion conducted by multinational companies (Darussalam \& Ngantung, 2018). However, along with the digital economy development, the concept of PE is not effective in capturing the tax potencies that arise from those activities (Hongler \& Pistone, 2015). On the other hand, OECD (2014) argues that significant digital presence or significant presence concepts will effectively and efficiently prevent base erosion conducted by digital multinational entities. Unfortunately, hitherto, there is no evidence that those concepts have effectively reduced the tax avoidance conducted by non-digital foreign taxpayers (Hongler \& Pistone, 2015). Therefore, in this section, we will seek for solutions with regard to how the SEP concept works with the PE concept.

Before redesigning the relation between PE and SEP concept, the PE concept evaluation is necessary to determine whether the SEP concept is effective enough to replace the PE concept in Indonesia's taxation system. Assume that SEP is the only concept that applies in Indonesia, and the Indonesian government will set a threshold in the SEP criteria, which includes the amount of consolidated turnover, the number of sales in Indonesia, or the number of active users in Indonesia. The Indonesian government no longer considers whether non-resident entities have a physical presence in Indonesia or not. As long as non-resident company activities exceed the established threshold, the Indonesian government can impose a tax on them.

Suppose that a foreign digital advertising company conducts activities in Indonesia by providing consultancy to ecommerce companies in Indonesia. The foreign advertising company is a start-up company. Therefore, the amount of consolidated turnover, the number of sales in Indonesia, and the number of active users in Indonesia are still below the Indonesian government threshold. To get new customers in Indonesia, the foreign start-up opened a representative office in Indonesia. Even though this company opened a representative office in Indonesia, the Indonesian tax authority cannot impose a tax on this non-resident company because Indonesian tax authority no longer uses the PE concept. On the other hand, the SEP concept also cannot capture this activity since this activity is under the threshold.

Based on the above scenario, we can find out that the SEP concept is not effective in capturing all economic activities. We may say that the Indonesian government can tighten the threshold so that companies with low consolidated turnover or low-sales sales can generate taxable presence in Indonesia. However, tightening the threshold is not a good option. According to Hongler and Pistone (2015), if the tax authority sets a tight 
threshold, excessive fragmentation of worldwide income will occur. This condition will cause a higher number of tax disputes. As a result, the SEP concept's use has become ineffective due to the increased tax dispute costs incurred. To overcome the PE and SEP concept problem, I propose that the implementation of the SEP concept can be combined with the concept of PE. In other words, the SEP concept complementsthe PE concept. To avoid overlapping the application of two concepts, I suggest that tax jurisdiction carries out sequential testing, as shown in Figure 3.

Based on Figure 3, we can see that if non-resident entities meet the PE test, the PE exists and is subject to income tax. On the other hand, if non-residents do not meet the PE test nor the SEP test, the PE does not exist, and the Indonesian government has no right to tax the non-resident entities. However, if non-resident entities do not meet the PE test but meet the SEP test, two possibilities arise. First, if there is no tax treaty provision that specifically regulates the establishment of PE, the non-resident entities will be subject to income tax under the Indonesian domestic taxation system. Second, if the PE does not exist due to a specific tax treaty provision, the activities carried out by the digital advertiser will be subject to the electronic transaction tax.

To avoid the contradiction between the PE concept and the SEP concept, the Indonesian government should modify the provision of PE exemption to clarify a contradiction between PE provision and add value creation in the existing regulation. The Indonesian PE provision stipulates that supporting and auxiliary activities such as warehousing, delivery, data collection, and survey are excluded from the establishment of PE. However, these supporting and auxiliary activities give rise to higher added value under the SEP concept. For example, information-gathering activities about consumer behavior carried out by digital advertising companies through surveys are generally considered auxiliary activities because they are not the main activity. Therefore, under the PE concept, this activity does not cause a taxable presence because it is categorized as an auxiliary activity.

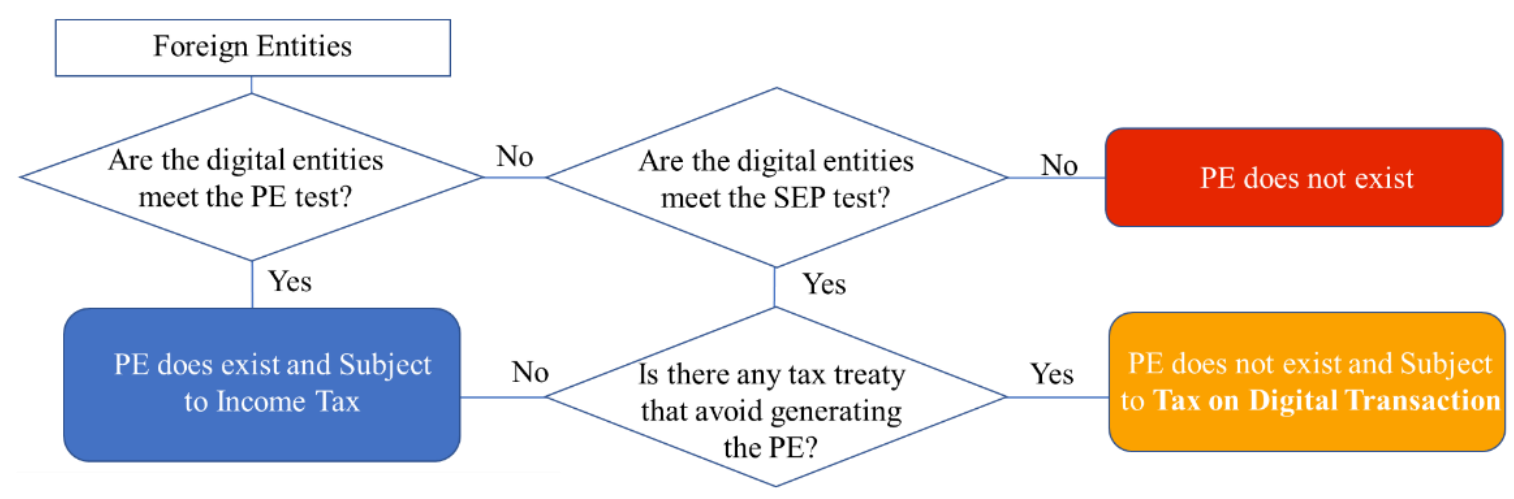

Figure 3 Proposal on taxable presence 


\subsection{Designing Tax Method for Digital Advertising}

As explained in the previous section, the implementation of the SEP concept has two implications. Firstly, non-resident entities will be subject to income tax under domestic regulations in Indonesia. Alternatively, nonresident entities will be subject to a new type of tax, namely electronic transaction tax. Unfortunately, the Indonesian government has not set further regulations regarding the mechanism of these types of tax. This section tries to solve this problem by proposing several approaches to taxing digital advertising.

Hongler and Pistone (2015) argue that a good taxation method should be as detailed as possible and consider the characteristics of taxed transactions. Therefore, the policy option applied to the advertising digital should be able to calculate the tax amount accurately but efficiently applied and minimize the tax disputes with other tax authorities. Alternatively, the Indonesian tax authority can use several revenue drivers, such as the number of clicks, views, and responses as a basis for taxation. Statistical data showed that most of the Indonesian digital advertising is dominated by search advertising, social media advertising, and banner advertising that use the number of clicks and the number of views as revenue drivers. In order to accommodate this idea, this policy paper proposes the number of clicks and number of views from Indonesia IP address as a basis to impose a tax on digital ad activities.

On the first occasion, we will discuss the taxation method for digital advertisers with PE in Indonesia. In the Indonesian domestic tax regulations, PE status has the same tax rights and obligations as domestic taxpayers in Indonesia. Generally, if domestic taxpayers carry out cross border transactions, they will use the Transfer Pricing method in calculating the number of tax liabilities. Therefore, for digital

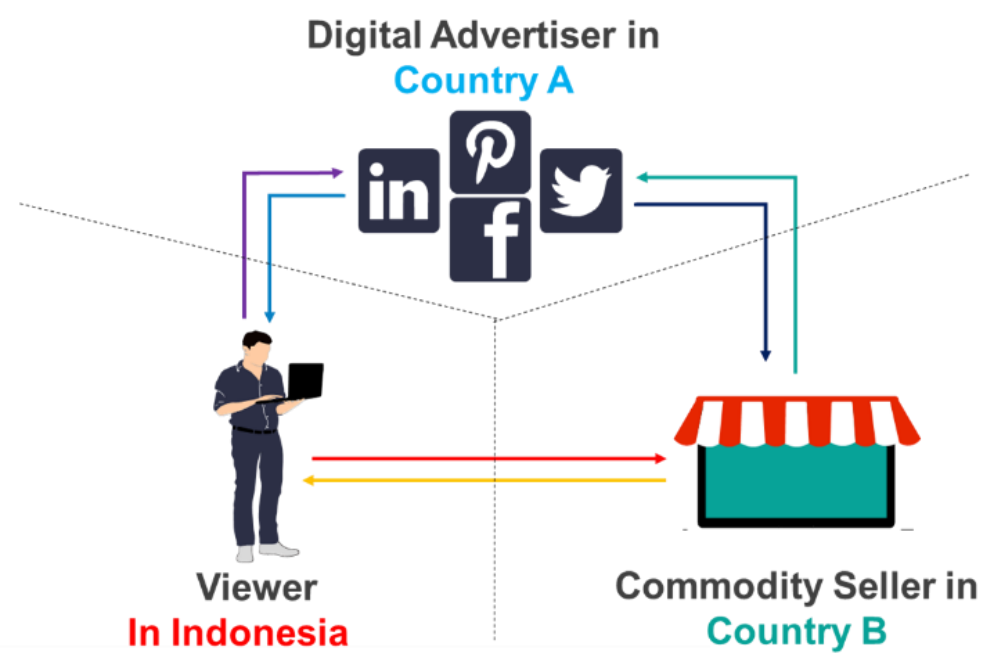

Figure 4 Digital advertising process business 
advertisers who have PE in Indonesia, we can use the TP method in the form of a Transactional Net Margin Method (hereafter referred to as TNMM) and Profit Split Method (hereafter referred to as PSM) to determine the number of tax liabilities. The basic idea of this concept is to use the number of clicks, views, and responses as a global profit-sharing factor because revenue from digital advertisers is primarily determined by the number of clicks, views, and responses. To apply this idea, we should know the amount of the global income under the arms-length principle beforehand. After knowing the companies' profit under the arms-length principle using the TNMM, we divide the global profit based on the number of clicks, views, and responses from Indonesia.To calculate the number of tax liabilities, we can multiply the proportion of Indonesia's profits with an effective rate of Corporate Income Tax (hereafter referred to as CIT).
For an illustration, we can see Figure 5. Suppose that a business group conducts its digital advertising business activities through a platform in 3 different countries: Indonesia, Singapore, and Malaysia. In Indonesia, this platform gained 10,000 clicks. In Singapore, this platform got 20,000 clicksand in Malaysia, this platform got 30,000 clicks. To determine the number of tax liabilities, the first step that should be taken is conducting a TP analysis using the TNMM method. The TNMM analysis is essential in this process because it will provide information on the fair amount of net income in each country under the armslength principle. Based on TNMM analysis, it is known that through its PE in Indonesia, the business group has a net income of 70 While the PE in Singapore earns a net income of 90, and Malaysia's PE earns a net income of 100. In the second step, we can calculate the amount of consolidated net income holding company in country A by adding up the net income of each country. Based on the

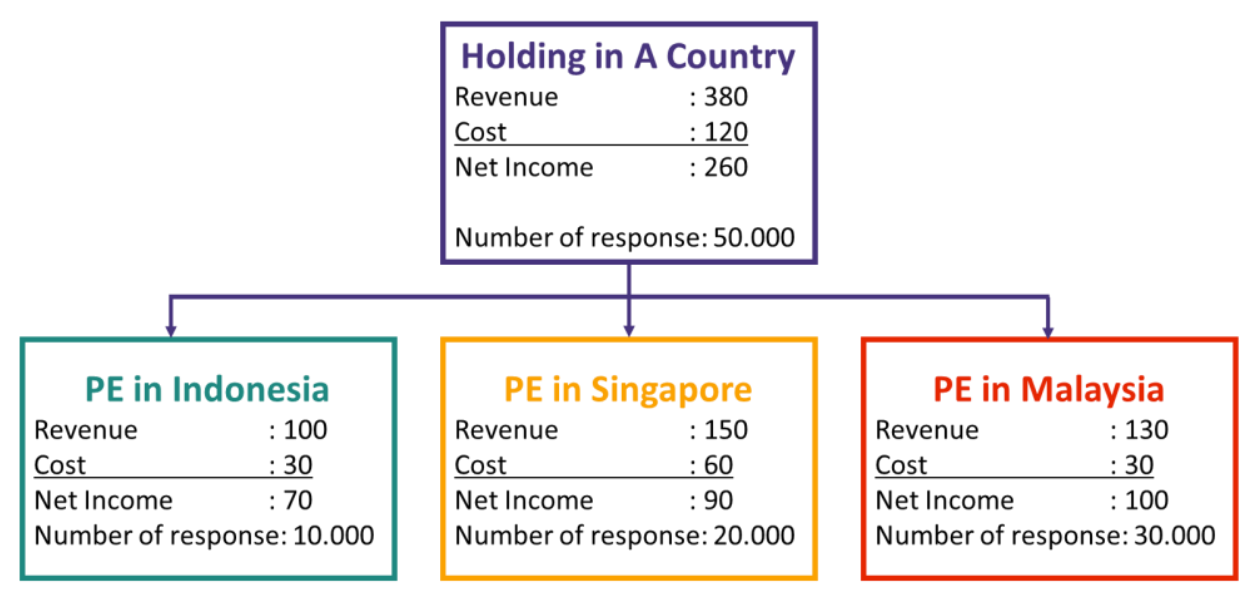

Figure 5 Proposal on taxation method 1 
information above, it is known that the holding company in country $A$ has a net income of 260 and a total click of 50,000. In the third step, to calculate the amount of tax owed in Indonesia, we can use the PSM method by dividing the number of clicks from Indonesia by the number of consolidated clicks and then multiplying by the consolidated net income. In this case, we can divide 10,000 by 50,000 then multiply it by 260 and the effective rate of CIT by $25 \%$. As a result, the amount of tax owed in Indonesia is 13 .

On the second occasion, we will discuss the taxation method for the digital advertiser that meets the PE test and SEP test but does not have PE in Indonesia. For digital advertisers who have met the PE test and the SEP test, but PE does not exist due to the tax treaty provisions, we can use the approach proposed by the OECD in the taxing method. However, before using the OECD approach, we must evaluate whether the approach proposed by the OECD is effectively applied to digital advertising transactions. The first approach proposed by OECD is to apply a withholding tax to the digital economy. Based on our analysis, the withholding tax is only effectively applied to $\mathrm{B} 2 \mathrm{~B}$ transactions. Withholding tax is less effective for B2C and C2C transactions because withholding tax requires a contract or agreement to withhold the income. It would be challenging to ask the parties to make withhold contracts. Also, withholding tax is only effective for passive income, such as interest and dividends. Based on this analysis, we believe that the withholding tax is not so comprehensive and effective for taxing digital advertising.

The second approach proposed by the OECD is to use turnover tax for digital economy activities. The turnover tax has been adopted by many countries such as India, Italy and France due to its ease of application. However, the turnover tax generally cannot precisely calculate the number of tax liabilities because turnover tax uses a single rate. Also, the difference in turnover tax rates between countries triggers digital advertising players to move profits from one country to another. Based on this, in our perspective, turnover tax is not so comprehensive and effective for taxing digital advertising.

The final proposal submitted by the OECD is a special measure to tax digital advertisement engaged by big MNE as implemented by the UK government. This approach only effectively captures the potential tax from large digital advertisers like Google and Facebook. Generally, this approach is not effective for small and medium digital advertisers because small and medium digital advertisers are inelastic to changes in tax rates (Ihori, 2017). It implies that SMEs are not really affected by the change of tax rate. In addition, the facts show that multinational companies can still move profits to other countries even though the DPT provides a deterrent effect (Fuchs, 2018). Based on the analysis and conditions of digital advertising in Indonesia, we believe that the approach proposed by the OECD may be appropriate for digital transactions in general. However, for digital advertising, 


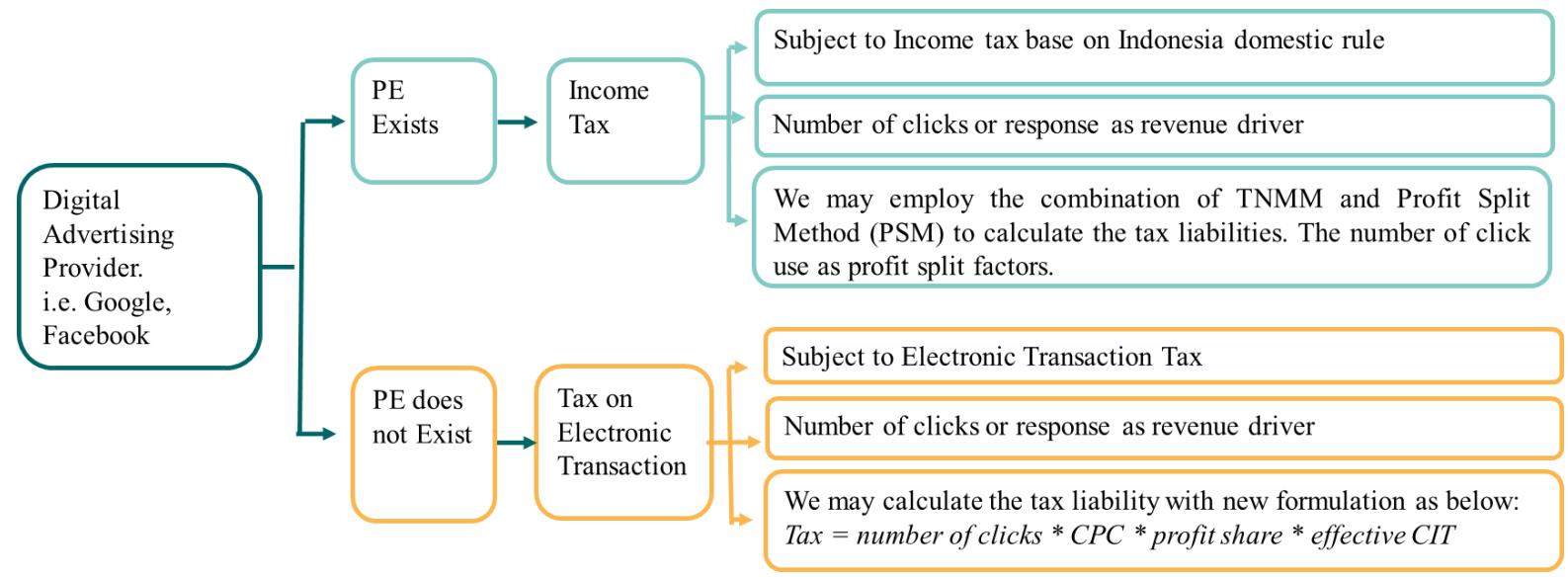

Figure 6 Proposal on taxation method 2

especially in Indonesia, we suggest that the number of tax liabilities is calculated by multiplying the number of clicks, views or responses with CPC (hereafter referred to as

\section{Tax payable}

\section{$=$ number of clicks or views $x$ effective rate of CIT $x$ prof it sharing $x$ Average CPC}

The Indonesian authority can obtain information about the number of clicks, views, and responses generated from Indonesia in three ways. Firstly, the Indonesian tax authority can ask the digital advertiser to submit the tax return to obtain data on the number of clicks, views, responses. Digital advertisers like Google and Facebook can provide complete data about the number of clicks, views, traffic sources, income generated, CPC, VPC, and many other data. Therefore, the Indonesian tax authority can ask the digital advertiser to submit those data in the tax return form. The tax authority utilizes the digital advertiser data as the primary source in determining the digital ad tax. Second, the Indonesiantax authority can also ask the Indonesian
(PC) or cost per view (hereafter referred to as VPC), profit sharing, and effective rate of CIT. Mathematically, the calculation can be described as follows:
Statistic Bureau to provide data regarding the number of clicks, views, or responses. The data provided by Indonesian statistical agencies can be used as secondary data to conduct a comparability test. According to Government Regulation Number 80, the year 2019, regarding e-commerce, the digital advertiser should submit the statistical data to the Indonesian statistic institution. Therefore, we can use the Indonesian Statistical Bureau data as a complement data in determining the tax liabilities. The third data source that can be used by the tax authority is statistical data from independent institutions.

The information with respect to the number of clicks, views or responses does not have any meaning if we do not have any 
information as to the revenue generated in every click or view. Perhaps, the information about the CPC and VPC is the most essential thing in determining the tax on digital advertising. However, it is not easy to know CPC or VPC because each advertiser has its formula for determining its pricing method. Besides, one advertiser with another advertiser is non-comparable because each advertiser has different functions, assets, and risks. For example, Google determines the CPC and VPC based on competitor rank and advertiser quality score in a bidding process. According to WorldStream (n.d.), CPC is the actual cost paid by advertisers in a pay per click program. Moreover, WorldStream (n.d.) also argues that advertisers' actual view per clicks depends on competitors' ad rank and advertiser quality scores. On the other hand, Facebook uses a more sophisticated pricing method because it involves several variables: audience, client budget, bid process, advertisement objective, advertisement placement, advertisement quality, season, and industry. Therefore, the CPC and VPC that generated from one sector will be different from the other. Also, advertisements published on the weekend will create different CPC, and VPC compares it to an ad posted on weekdays.

To overcome the problem in pricing differences, the tax authority can use statistical data from the Indonesian Statistical Bureau and independent statistical agency as comparative data. The data from the Indonesian Statistical Bureau and the independent statistical agency is analyzed using one analytical method to determine the right CPC or VPC for each auction. According to Goldfarb and Tucker (2011), one way that can be used to estimate the magnitude of the cost of a click and view per click is the difference in differences method. Using keyword specifiers in search engine advertising, Goldfarb and Tucker (2011) try to analyze the influence of keywords on both CPC and VPC. However, the use of the difference in difference method in analyzing CPC and VPC seems inefficient and ineffective because there are many keywords to be analyzed to determine the amount of CPC and VPC. Other opinions expressed by the researchers from the University of Southern California and Fudan University. According to Yang, Lu, and Lu. (2014), information about value per click is confidential, so it is not easy to find it. Therefore, Yang et al. (2014) try to do the modeling based on the Nash equilibrium:

$$
\begin{gathered}
C P C_{k i}=\delta_{k j k i} C P C_{k i}+\left(1-\delta_{k j k i}\right) S_{k i} \\
\left\{S_{k i}\right\}_{j k i=2}^{n k}=\text { are } 1,2, \ldots, n_{\mathrm{k}}-1
\end{gathered}
$$

Yang et al. (2014) argues that i refers to advertiser under advertiser $\mathrm{i}$ and Ski is iid (identically, independent, distributed). By implementing this method, we can get the average CPC and VPC to calculate the tax payable. Facebook, for example, has a CPC of $\$ 0.97$ and a cost per download of $\$ 5.47$. In the other hand, Google has a CPC of $\$ 1$ to $\$ 2$.

The effective rate of $\mathrm{CIT}$ is useful as a domestic tax rate imposed on all economic activities. Therefore, the use of CIT will 
provide justice to all economic actors because digital advertising companies and non-digital advertising companies will be subject to the same tax rate of $25 \%$ according to the income tax act in Indonesia. Furthermore, the use of profitsharing factors will improve taxation accuracy because taxes are levied on profits rather than business circulation. By using the profit-sharing factor, the tax authority considers the costs of digital advertising as a factor of profit reduction. This issue will undoubtedly increase the trust of digital advertising companies because of the fairer taxation treatment compared to the use of withholding tax and turnover tax. We can find out the profit-sharing factor by looking at the digital advertising financial statements as well as from the digital advertising business scheme. Google (n.d), for example, argues that as much as $68 \%$ of Google's revenue received through Google AdWords is paid to the Google AdSense content provider. So, it can be concluded that Google's profit-sharing factor from advertising activities is about $32 \%$. Third, the use of CPC and VPC will increase the accuracy of taxation because taxes are imposed at the level of transactions per transaction. Although the CPC and VPC algorithms seem complicated and confusing, we can use the average CPC and VPC as the basis for taxation. For example, in 2019, the average rate of Google CPC is $\$$ 1 , and Facebook CPC is $\$ 0.98$.

\subsection{Intercorrelation The Proposals with OECD Pillar One and Two}

According to OECD (2021), pillars one and two will be effectively implemented in 2023. Therefore, the digital advertising taxation as proposed in this paper should be in line with pillars one and two proposed by OECD. Even though, during 2021 and 2022, there will be a series of discussions on these pillars.

According to the author, PE test and SEP test proposals as described in chapter 5.1 meet the requirements in pillar one proposed by OECD. In SEP test which author proposed, the tax jurisdiction should assess whether the electronic advertisement transaction meets the minimum threshold as proposed in pillar one. Therefore, to meet pillar one, the Indonesian government may set a minimum threshold of 1 million euros or equals to16,8 billion rupiahs. However, because the Indonesian GDP was below 40 billion USD in 2020, the Indonesian government may set a threshold of 250.000 euros or 4,2 billion rupiahs under OECD pillar one.

The 250 euros or 4.2 billion rupiahs threshold is much higher than the threshold for electronic VAT regulated in the Minister of Finance Regulation No. 48 of 2020. Through this regulation, the Indonesian government stipulates that electronic transactions will be subject to VAT in Indonesia if the transaction value exceeds 600 million Rupiah. Therefore, the digital advertising tax threshold, as discussed in 5.1, must match the electronic VAT threshold to ensure equal treatment between income tax and VAT.

On the other hand, according to the author, the taxation method proposed in 
chapter 5.2.3 is also following pillar two. By imposing a digital advertising tax, there will be no possibility for foreign entities not to pay income taxes in Indonesia as long as they meet the minimum threshold. However, the OECD (2021) states that the application of pillars one and two will lead to the abolition of the digital service tax. Therefore, when applying pillars one and two, proposals regarding digital advertising tax must be adjusted to the provisions of pillars one and two in Indonesia.

\subsection{Tax Administration Support}

After understanding the proposals regarding the taxable presence and tax method, we may ask how to implement these proposals into the Indonesian taxation system. To answer this question, we may see Figure 7. In Figure 7, we can see that the non-resident taxpayers submit the tax return to the tax authority. The tax return contains information about the number of clicks,
Indonesian tax authority compiles the tax returns submitted by the non-resident entities. On the other hand, the Indonesian tax authorities ask the Indonesian Statistics Bureau to provide data about the numbers of clicks, CPC, or VPC who will capture the data from the Ministry of Informatics and independent statistical organization. Furthermore, the Indonesia statistics bureau can get the data of CPC or VPC by employing mathematical calculations as below:

$$
C P C_{k i}=\delta_{k j k i} C P C_{k i}+\left(1-\delta_{k j k i}\right) S_{k i}
$$

Statistic data submitted by the Indonesian Statistical Bureau isused as the comparable data by the Indonesian tax authority in conducting tax examination, especially transfer pricing tax examination. Moreover, the tax authority can also ask taxpayers to submit a TP documentation such as Masterfile, Local File, and Country by Country Report to conduct tax examination.

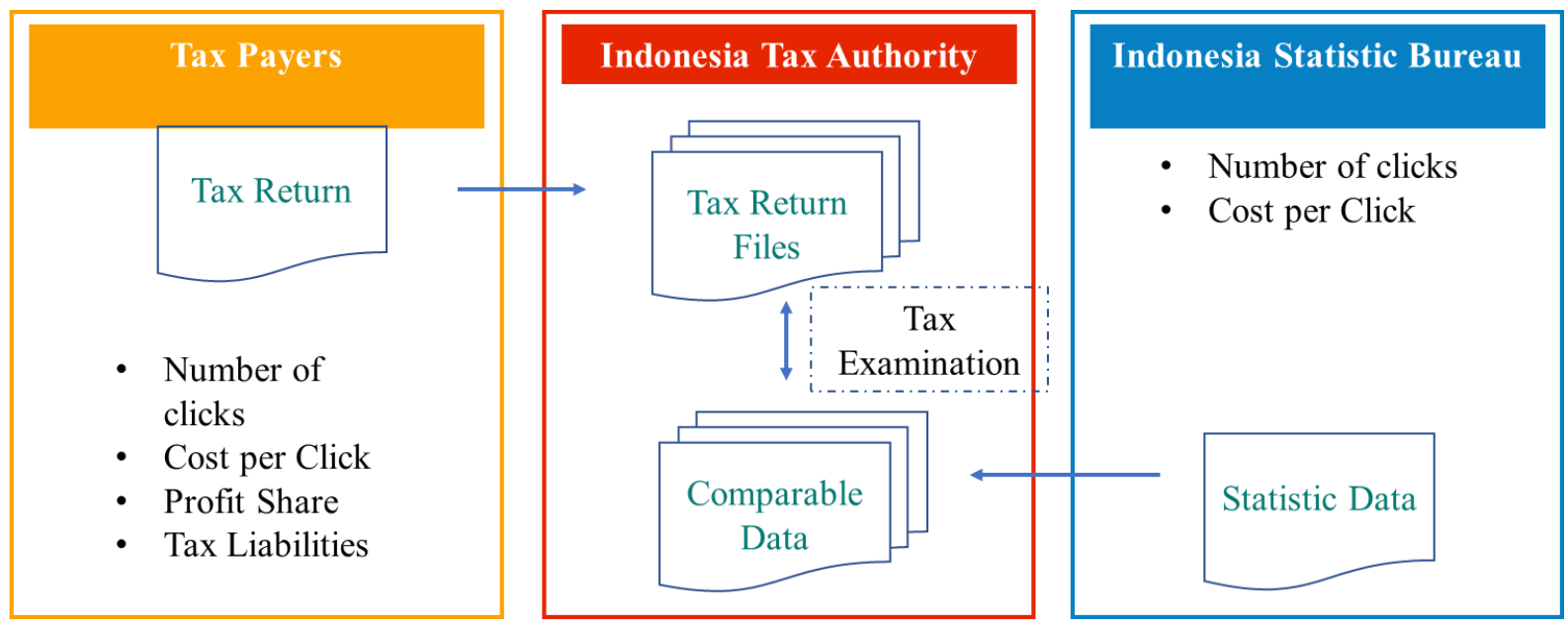

Figure 7 Proposal on tax administration support 


\section{CONCLUSION}

The development of digital technology not only provides convenience in conducting economic transactionsbut also poses challenges to the tax authority. One of the challenges that arise in the taxation field is the ineffectiveness of the PE concept in capturing the tax arising from the digital economic transaction. To reduce the negative impact arising from the digital economy, the Indonesian government plans to implement the SEP concept starting in 2020. However, so far, there has been no study examining whether the concept of SEP effectively replaces the PE concept. Moreover, there also has been no study that discusses how PE and SEP concepts are related to the Indonesian taxation system. This study investigates whether the concept of SEP effectively reduces externalities arising from the development of the digital economy, especially digital advertising. Furthermore, this study also aims to investigate how the relationship between the concepts of PE and SEP in facing the tax challenges arising from the digital economy.

In order to do this research, the PE test and SEP test simulations are conducted to examine whether the PE and SEP concept is effective and efficient in capturing the digital and non-digital economic activities in Indonesia. The result of the simulation shows that the concepts of PE and SEP have different aspects. The PE concept is only effective in capturing the taxation potencies that arises from the non-digital economy. On the other hand, the SEP concept only effectively captures the potential tax arising from digital economic activities. To overcome this problem, we propose to combine the PE test with the SEP test in a sequential test. The sequential test is necessary to avoid the overlapping between the PE test and the SEP test. Moreover, to prevent the contradicting between those two concepts, the Indonesia government needs to modify the provision regarding PE exemption.

The result of the simulation also shows that the implementation of the SEP concept will generate a new kind of tax in the Indonesian taxation system, namely electronic transactions tax. Unfortunately, the Indonesian government has not yet determined the form and mechanism of this new tax type. The evaluation through OECD proposals on taxation methods is necessary to provide the best alternative taxation method in digital advertising. After we evaluate the OECD proposal on the taxation method and the taxation method implemented by the OECD countries, we may conclude that there is no single taxation method that covers all digital transactions. The taxation method should consider the characteristic of each transaction. Therefore, this study proposes to impose a tax on digital advertising bases on the number of clicks, views, or responses received by digital advertisers. The tax authority can get the data number of clicks, views, or responses from the tax return submitted by the nonresident digital advertiser, or alternatively, by asking the Indonesian Statistic Bureau to 
provide the data. Both data can either be compared or complement each other.

The technology development is very dynamic. The digital advertiser can easily change the algorithm to determine the number of clicks, views, responses, CPC, VPC, and profit-sharing. Therefore, not only further study should also address this issue, but the taxation method should also be developed to prevent the practice from happening.

\section{REFERENCES}

[1] Bohang, F.K. (2018). Menkominfo: Facebook belum bayar pajak di Indonesia [Ministry of Informatics: Facebook has not paid any tax in Indonesia]. Kompas. Retrieved July 16, 2020 from

https://tekno.kompas.com/read/2018/05/07/17 235387/menkominfo-facebook-belum-bayarpajak-di-indonesia

[2] Darcy, J.W. (2019). Japan master tax guide

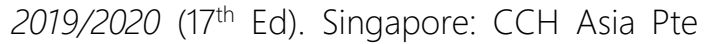
Limited

[3] Darussalam \& Ngantung, Y.W. (2018). Bentuk Usaha Tetap [Permanent Establishment]. In Darussalam \& D. Septriadi (Eds.), Perjanjian penghindaran pajak berganda: Panduan, interpretasi dan aplikasi [Tax treaty: Guidance, interpretation and application] (pp. 109-150). Jakarta: Penerbit DTCC.

[4] Das, K., Gryseels, M., Sudhir, P. \& Tan, K.T. (2016). Unlocking Indonesia's digital opportunity. Retrieved March 2, 2020. from https://www.mckinsey.com/featured-

insights/asia-pacific/unlocking-indonesiasdigital-opportunity

[5] Fuchs, C. (2018). The online advertising tax as the foundation of a public service internet. London: University of Westminster Press.
[6] Fuchs, C. (2018). The online advertising tax. London: University of Westminster Press.

[7] Goldfarb, A., \& Tucker, C. (2011). Search engine advertising: Channel substitution when pricing ads to context. Management Science, 57(3), 458470. https://doi.org/10.1287/mnsc. 1100.1287

[8] Google. (n.d.). Google adsense. Retrieved April 30, 2020 from https://www.google.com/adsense/start/

[9] Google, Temasek, Bain \& Company. (2019). eConomy SEA 2019: Swipe up and to the right: Southeast Asia's $\$ 100$ billion internet economy. Retrieved March 04, 2020 from https://www.thinkwithgoogle.com/intl/enapac/tools-resources/research-studies/economy-sea-2019-swipe-up-and-to-the-rightsoutheast-asias-100-billion-internet-economy

[10] Government Regulation of Republic Indonesia No. 80/2019. E-commerce. (2019)

[11] Government Regulation of Republic Indonesia in Lieu of Law No. 1/2020. State's Financial Policy and Financial System Stability for Handling the Coronavirus Pandemic. (2020)

[12] Helianthusonfri, J. (2018). Passive income dari Google adsense: Panduan menghasilkan passive income dari Youtube dan blog melalui Google adsense [Passive income from Google adsense: Guide to generating passive income from Youtube and blogs through Google adsense]. Jakarta: Elex Media Komputindo

[13] Hongler, P., \& Pistone, P. (2015). Blueprints for a new PE nexus to tax business income in the era of the digital economy (IBFD Working Paper 01/20/2015). Retrieved June 11, 2020 from https://www.ibfd.org/sites/ibfd.org/files/conten t/pdf/Redefining_the_PE_conceptwhitepaper.pdf

[14] Ihori, Toshihiro. (2017). Principles of Public Finance. Singapore: Springer

[15] Income Tax Law. (2008). Retrieved May 7, 2020 from https://www.pajak.go.id/id/undangundang-nomor-36-tahun-2008

[16] Kemp, S. (2020). Digital 2020: Indonesia. Retrieved May 14, 2020 from 
https://datareportal.com/reports/digital-2020indonesia

[17] Minister of Finance Regulation No. 35/PMK.03/2019. Permanent Establishment. (2019)

[18] Organization for Economic Cooperation and Development. (2017). Model tax convention on income and on capital: Condensed version 2017. https://doi.org/10.1787/mtc_cond-2017-en

[19] Organization for Economic Cooperation and Development. (2018). Tax challenges arising from digitalisation-interim report 2018: Inclusive framework on BEPS (OECD/G20 Base Erosion and Profit Shifting Project). https://doi.org/10.1787/9789264293083-en

[20] Organization for Economic Cooperation and Development. (2019). Online advertising: trends, benefits and risks for consumers (OECD Digital Economy Papers No. 272). https://doi.org/10.1787/1f42c85d-en

[21] Organization for Economic Cooperation and Development. (2020). Statement by the OECD/G2O Inclusive Framework on BEPS on the Two-Pillar Approach to Address the Tax Challenges Arising from the Digitalisation of the Economy. Retrieved June 11, 2020 from https://www.oecd.org/tax/beps/statement-bythe-oecd-g20-inclusive-framework-on-bepsjanuary-2020.pdf

[22] Organization for Economic Cooperation and Development. (2021). Addressing the tax challenges arising from the digitalisation of the economy. Retrieved August 19, 2020 from https://www.oecd.org/tax/beps/brochureaddressing-the-tax-challenges-arising-fromthe-digitalisation-of-the-economy-july2021.pdf

[23] Statista. (2020). Digital advertising: Indonesia. Retrieved May 5, 2020, from https://www.statista.com/outlook/216/120/digit al-advertising/indonesia

[24] Statistics Canada. (2016). Analysis in brief: Retail e-commerce in Canada. Retrieved July 15, 2020 from https://www150.statcan.gc.ca/n1/pub/11621-m/11-621-m2016101-eng.htm
[25] Susanti, I., Nasir, L.A. \& Sukardianti, V.P. (2017). Implementation of tax regulations on internetbased business activity case study: Google's tax avoidance in Indonesia. Advances in Social Science, Education and Humanities Research, 167, 387-397. https://doi.org/10.2991/icaspgsicbap-17.2017.8

[26] United Nations. (2017). United Nations model double taxation convention: between developed and developing countries. Retrieved June 9, 2020 from https://www.un.org/esa/ffd//wpcontent/uploads/2018/05/MDT_2017.pdf

[27] United Nations. (2019). Manual for the negotiation of bilateral tax treaties: Between developed and developing countries 2019. Retrieved May 14, 2020 from https://www.un.org/esa/ffd/wpcontent/uploads/2019/06/manual-bilateral-taxtreaties-update-2019.pdf

[28] WorldStream. (n.d.). Cost per click (CPC): Learn what cost per click means for PPC. Retrieved April 26, 2020 from https://www.wordstream.com/cost-per-click

[29] Yang, S., Lu, S., \& Lu, X. (2014). Modelling competition and its impact on paid-search advertising. Marketing Science, 33 (1), 134-153. http://dx.doi.org/10.1287/mkcs.2013.0821 